\title{
Politik Hukum Hak Asasi Manusia di Indonesia
}

\author{
Moh. Mahfud MD
}

\section{Abstract}

Aithough Indonesia has adopted the principles of legal state (the rule of law) and democracy the abuse of human rights, particularly the massive and intensive abuse forms, still occurs. This article tries to overview the problem in the legal politic aspects, considering the available legal instrument and formulation in the constitution and the legal devices of its enforcement. For short term of legal politics, there is a faced dilemma; i.e. doing the brave and strict settlement until court, or conducting whitening by fair reconciliation. The choice between the two sides should be quickly carried out by previously calculating its procedural-technical obstructions and its political ones.

\section{Pendahuluan}

Politik Hukum HAM diartikan sebagai kebijakan hukum (legal policy) tentang HAM yang mencakup kebijakan negara tentang bagaimana hukum tentang HAM itu telah dibuat dan bagaimana pula seharusnya hukum tentang HAM itu dibuat untuk membangun masa depan yang lebih baik, yakni kehidupan negara yang bersih dari pelanggaran-pelanggaran HAM, terutama yang dilakukan oleh penguasa. ${ }^{1}$

Salah satu persoalan besar yang dihadapi bangsa Indonesia sekarang ini adalah bagaimana menyelesaikan kasus-kasus pelanggaran HAM yang terjadi di masa lalu serta bagaimana menyiapkan perangkat hukum yang lebih responsif agar pada masa

${ }^{1}$ Pengertian seperti ini digunakan juga sebagai definisi konsep tentang politik hukum untuk disertasi saya, Moh. Mahfud MD. "Perkembangan Politik Hukum, Studi tentang Pengaruh Konfigurasi Politik terhadap Karakter Produk Hukum di Indonesia." Disertasi Program Pasca Sarjana UGM. Yogyakarta. 1993. 
mendatang pelanggaran-pelanggaran HAM, terutama yang dilakukan oleh negara, dapat dihindari. ${ }^{2}$ Sampai saat ini banyak agenda reformasi yang belum bisa dilakukan dengan sungguh-sungguh karena bangsa Indonesia berkutat dengan persoalan-persoalan untuk menyelesaikan pelanggaran HAM di masa lalu tanpa arah yang jelas. Sementara bangsa Indonesia terus berkutat untuk mencari penyelesaian pelanggaran HAM dan KKN lainnya yang terjadi di masa lalu, kasus-kasus KKN baru mulai bermunculan sehingga agenda reformasi Indonesia mulai menghadapi ancaman yang cukup serius. Ancaman ini menjadi serius karena kalau tidak dapat segera memberi solusi atas pelanggran HAM dan kasus-kasus KKN yang terjadi di masa lalu, maka upaya reformasi akan menghadapi kesulitan karena pemain-pemain politik barupun yang tadinya hadir ke pentas politik atas nama reformasi akan ikut pula menghambat pemberantasan KKN karena dirinya juga sudah terjangkit penyakit KKN.

Kenyataan bahwa pada masa lalu di Indonesia sangat banyak terjadi pelanggaaran HAM yang kebanyakan dilakukan oleh aparat resmi tentu mengherankan, sebab negara ini didirikan di atas prinsip negara hukum. Penerimaan Indonesia atas prinsip negara hukum ini bukan hanya karena bunyi penjelasan UUD 1945 yang pada kunci pokok pertama Sistem Pemerintahan Negara menyebutkan bahwa: "Indonesia adalah negara yang berdasar hukum (rechstaat)..." melainkan juga karena alasan-alasan lain seperti yang dituangkan di dalam Pembukaan maupun di dalam Batang Tubuh UUD 1945 sendiri. ${ }^{3}$ Baik isi Pembukaan maupun Batang Tubuh yang secara tegas menyebut adanya prinsip demokrasi dan pengakuan serta perlindungan HAM merupakan bukti bahwa Indonesia menganut prinsip negara hukum. Seumpama dibaratkan sekeping mata uang, prinsip demokrasi merupakan sisi mata uang yang sebelahnya lagi. Keduanya memiliki hubungan kerja yang saling bergantung karena demokrasi tidak akan terlaksana tanpa negara hukum dan negara hukum tidak akan tegak tanpa demokrasi. ${ }^{4}$ Begitu juga adanya pengakuan dan perlindungan atas HAW (Hak Asasi Warga Negara) oleh Pembukaan dan Batang Tubuh UUD 1945 merupakan bukti lain bahwa Indonesia merupakan negara yang berdiri di atas prinsip negara hukum. ${ }^{5}$ Bahkan

\footnotetext{
${ }^{2}$ Melihat pengalaman masa lalu, maka ada dua hal yang perlu diakomodasi di dalam politik hukum indonesia, yaitu menyiapkan perangkat hukum yang memadai dan memberi solusi atas kasus yang telah terjadi tetapi belum mendapat cara penyelesaian yang elegan.

${ }^{3}$ Selama ini sering dinyatakan bahwa penganutan prinsip negara hukum di Indonesia didasarkan pada adanya penegasan di dalam Penjelasan UUD 1945 bahwa Indonesia adalah negara yang berdasar atas hukum (rechtstaaf), padahal bukan hanya karena itu melainkan terutama karena adanya penerimaan atas prinsip demokrasi dan konstitusi itu sendiri.

${ }^{4} \mathrm{Negara}$ adalah organisasi kekuasaan, sedangkan hukum dibuat agar organisasi itu berjalan dengan baik. Mochtar Kusumaatmaja lebih spesifik menggunakan istilah kekuasaan dalam adagium ini ketika mengatakan bahwa "kekuasaan tanpa hukum itu dzalim, hukum tanpa kekuasaan itu lumpuh".

${ }^{5}$ Semua konsepsi negara hukum yang pernah dikemukakan oleh para pemikir tentang negara dan hukum selalu meletakkan gagasan perlindungan HAM sebagai ciri utamanya.
} 
adanya konstitusi sendiri merupakan bukti pula bahwa Indonesia ini menganut prinsip negara hukum dan demokrasi sebab secara sosiolegal dan sosio-kultural adanya konstitusi itu merupakan konsekuensi dari penerimaan atas prinsip negara hukum dan demokrasi.

Penegasan bahwa penganutan prinsip negara hukum oleh Indonesia ini bukan hanya didasarkan pada bunyi Pēnjelasan UUD 1945 tentang "rechtstaat". sangat penting secara akademis karena keberadaan Penjelasan itu sendiri masih sering dipersoalkan sebagai produk yang semula tidak sah. Seperti diketahui baik badan Penyelidik Usaha-Usaha Persiapan Kemerdekaan Indonesia.(BPUPKI) maupun Panitia Persiapan Kemerdekaan Indonesia (PPKI) tidak pernah merancang apalagi memutuskan Penjelasan UUD 1945 tersebut. Naskah Penjelasan, yang banyak dipercaya sebagai karya pribadi Soepomo itu, tiba-tiba muncul menjadi lampiran UUD 1945 ketika UUD tersebut ditempatkan di dalam lembaran Negara Tahun II No. 7 Tahun $1946 .{ }^{6}$ Jadi, seumpama pun tidak percaya bahwa Penjelasan itu merupakan hasil kesepakatan para pendiri negara, maka kenyataan bahwa Indonesia menganut prinsip negara hukum tetap tidak dapat dibantah sebab penerimaan Indonesia atas prinsip negara hukum itu bukan karena adanya bunyi Penjelasan UUD 1945 melainkan karena adanya konstitusi itu sendiri yang di dalamnya memuat prinsip demokrasi yang disertai ciri-ciri bagi adanya negara hukum.

\section{Pelanggaran HAM yang Massif}

Seperti telah dikemukakan di atas, meskipun Indonesia menganut prinsip negara hukum dan demokrasi serta memiliki konstitusi yang menyatakan pemihakan pada perlindungan HAM, ternyata Indonesia senantiasa terjadi pelanggaran. HAM yang sangat banyak, di antaranya dilakukan oleh aparat secara massif. Pada saat ini bangsa Indonesia masih bergumul di dalam pergulatan yang serius untuk mencari penyelesaian bagi kasus-kasus pelanggaran HAM yang terjadi masa lalu, terutama yang sifatnya massif telah dilakukan oleh aparat yang dalam banyak kasus merupakan pelanggaran HAM yang berat. Adapun pelanggaran HAM berat, menurut Pasal 5 Rancangan Undang-Undang Pengadilan $\mathrm{HAM}^{7}$ adalah pelanggaran $\mathrm{HAM}$ yang meliputi:

a. Setiap perbuatan yang dilakukan dengan maksud untuk menghanciurkan atau memusnahkan seluruh atau sebagian kelompok kebangsaan, ras, kelompok etnis, kelompok agama, atau kelompok manapun juga yang berbeda warna kulit, jenis kelamin, umum, atau cacat fisik dan atau mental, dengan:

1) Membunuh anggota kelompok;

2) Mengakibatkan penderitaan fisik atau mental yang berat terhadap anggota kelompok;

${ }^{6}$ Meskipun UUD 1945 telah disahkan tanggal 18 Agustus 1945 oleh PPKI namun pengundangannya di dalam Lembaran negara baru dilakukan pada tahun 1946 dan pada saat itulah tiba-tiba disertakan naskah Penjelasan tersebut tanpa pernah dibahas oleh forum resmi PPKL.

${ }^{7}$ RUU tentang Pengadilan HAM telah disampaikan oleh Pemerintah kepada DPR dan telah mulai dibahas sebagai konsekuensi dari penolakan DPR atas Perpu No. 1 Tahun 1999. 
3) Sengaja menciptakan kondisi kehidupan kelompok yang akan mengakibatkan kemusnahan secara fisik baik seluruhnya atau sebagian;

4) Memaksakan tindakan-tindakan yang bertujuan mencegah kelahiran di dalam kelompok; dan atau

5) Memindahkan secara paksa anakanak dari kelompok tertentu ke kelompok lain.

b. Membunuh orang atau kelompok orang dengan cara sewenang-wenang di luar batas kemanusiaan dan atau di luar putusan pengadilan;

c. Segala bentuk tindakan yang memaksa terjadinya pengungsian atau pemindahan orang atau kelompok orang atas dasar alasan politik;

d. Menculik dan atau menghilangkan orang secara paksa;

e. melakukan perbudakan;

f. Melakukan diskriminasi terhadap orang atau kelompok orang yang dilakukan secara sistematis;

g. Melakukan penyiksaan;

h. Merusak, membakar dan atau disertai dengan penjarahan pada instalasi vital, sekolah, tempat ibadah, rumah sakit, pusat kegiatan ekonomi dan perdagangan, atau sarana transportasi atau meracuni obyekobyek kepentingan umum dan atau menebarkan bibit penyakit kepada masyarakat yang dilakukan secara massal; atau

i. Melakukan perkosaan secara massal dan sistematis, termasuk pelecehan seksual lain yang melanggar norma kesusilaan dan agama yang dilakukan terhadap kelompok atau golongan tertentu.

Tidak mudah bagi bangsa Indonesia untuk menyelesaikan pelanggaran HAM yang terjadi di masa lalu. Hasil temuan dan rekomendasi KPP HAM yang dibentuk oleh Komnas HAM baik untuk kasus pelanggaran HAM pasca jejak pendapat di Timor Timur tahun 1999 maupun untuk kasus pelanggaran HAM yang terkait dengan peristiwa Tanjung Priok pada tahun 1984 telah menimbulkan pro kontra yang belum memberikan arah penyelesaian yang jelas. ${ }^{8}$ Dalam masalah pelanggaran HAM yang terjadi di masa lalu memang belum mempunyai konsep yang dapat disepakati bersama sehingga menunjuk ke arah yang jelas. ${ }^{9}$

Sebenarnya masalah pelanggaran HAM di Indonesia bukan hanya terjadi dalam kasuskasus politik seperti kasus Timtim, Aceh, Lampung, Tanjung Priok, Maluku dan sebagainya melainkan terjadi juga dalam penanganan masalah-masalah kriminal yang biasa. masih banyak dijumpai dalam praktik penegakan hukum tindakan-tindakan yang melanggar HAM seperti yang dapat

9Masih segar dalam ingatan bangsa Indonesia, bahkan masih menjadi masalah sampai sekarang (bahwa) kesimpulan dan rekomendasi KPP-HAM tentang kasus Timor Timur dan kasus Tanjung Priok telah disambut dengan berbagai unjuk rasa dan ketidakpuasan.

'Lihat dalam Kompas Cyber Media. Edisi 28 Juni 2000. 
diinventarisasi ke dalam masalah-masalah sebagai berikut: ${ }^{10}$

1. Sering terjadi aparat penegak hukum melanggar HAM dan menangkap atau menahan seorang tersangka pelaku kejahatan dengan melakukan penangkapan tanpa surat perintah. Dalam kenyataannya sering juga terjadi penyitaan barang tanpa surat perintah dari pejabat yang berwenang atau tanpa putusan hakim bahkan yang sangat mengerikan adalah terjadinya penculikan-penculikan." Tindakan-tindakan semacam ini jelas melanggar hukum tentang. HAM sebab menurut Pasal 7 UU No. 14 Tahun 1970 (sebagaimana telah diubah dengan UU No: 35 Tahun 1999) tentang Ketentuanketentuan Pokok Kekuasaan Kehakiman setiap tindakan hukum penangkapan, penahanan, penggeledahan dan penyitaan hanya dilakukan berdasarkan perintah tertulis dari Pejabat yang diberi wewenang oleh Undang-Undang dan hanya dalam hal dan dengan cara yang diatur dengan Undang-Undang.

2. Tidak jarang pula muncul pesakitan yang hanya menjadi kambing hitam dari suatu tindak pidana yang berindikasi kuat dilakukan oleh aparat pemerintah maupun dilakukan oleh orang yang memiliki biaya untuk memunculkan kambing hitam. Kasus Iwik Dwisumaji yang dijadikan kambing hitam dalam kasus pembunuhan wartawan Bernas Fuad Muhammad Syafruddin (Udin) atau kasus Mutiari dan Judi Astono cs yang dijadikan kambing hitam dalam kasus. terbunuhnya buruh Marsinah dapat disebut sebagai contoh. Baik untuk mereka yang hanya dijadikan kambing hitam maupun untuk mereka yang secara hukum memang patut dijadikan tersangka dalam suatu tindak pidana seringkali dilakukan pelanggaran atas asas praduga tak bersalah (presumption of innocence) melalui penistaan atas nama baik oleh aparat penegak hukum seperti pemukulan, penyiksaan maupun penyidikan dengan membuat Berita Acara Pemeriksaan yang tanpa pro justisia. Ini terjadi bukan hanya dalam kasus tindak pidana melainkan juga dalam kasus yang sebenarnya hanya merupakan perkara perdata murni. Padahal menurut Pasal 6 UU No. 14 Tahun 1970 (sebagaimana diubah dengan UU No. 35 Tahun 1999) setiap orang yang disangka, ditangkap, ditahan, dituntut dan atau dihadapkan di sidang pengadilan wajib dianggap tidak bersalah sampai adanya putusan pengadilan yang menyatakan kesalahannya dan mempunyai kekuatan hukum tetap. Namun pada pihak lain dilihat juga bahwa terhadap banyak kasus dugaan korupsi

10Artidjo Alkostar. "HakAsasi manusia dalam prospek Penegakan Hukum Dewasa ini." Disampaikan sebagai Dies Rede pada Sidang Terbuka Senat Universitas Islam Indonesia Panitia Dies natalis UII ke-51 tanggal 29 Desember 1994.

"Tentang problema hukum dan politik mengenai penghilangan atau penculikan orang dapat dibaca di dalam "Pra-Lokakarya Kasus Orang Hilang: Pengungkapan dan Penyelesaian masalah" Seri Publikasi No.1I April 2000 yang diterbitkan oleh Kantor Menteri Negara Urusan HAM republik Indonesia. 
atau tindak pidana lain yang dịlakukan (mantan) pejabat tidak dilakukan tindakan hukum yang sungguh-sungguh, misalnya penyidikan, dengan alasan demi menegakkan asas pradúga tak bersalah. Jadi asas praduga tak bersalah diterapkan secara tidak konsisten, tergantung pada siapa terduga dan tersangkanya bahkan bergantung pada kemampuan untuk membayar sejumlah uang.

3. Banyak juga terjadi proses penanganan perkara di kepolisian yang memakan waktu sangat lama, bahkan melalui proses tawar menawar apakah perkara itu akan diteruskan ke pengadilan atau tidak. Tidak jarang ada perkara yang sampai dua tahun belum dilimpahkan ke pengadilan tanpa adanya Surat Perintah Penghentian Penyidikan (SP3). Padahal UU No. 14 Tahun 1970 (sebagaimana telah diubah dengan UU No. 35 tahun 1999) mengharuskan penerapan secara konsekuen proses peradilan yang cepat, sederhana, biaya ringan, bebas, jujur dan tidak memihak. Tidak jarang juga didengar adanya permintaan kompensasi dari penegak hukum kepada seorang tersangka untuk membayar sejumlah uang dengan imbalan bahwa perkaranya tidak akan diteruskan ke kejaksaan (atau dari kejaksaan tidak akan diteruskan ke pengadilan) melalui pengeluaran SP3. Jadi dilanjutkan atau tidaknya suatu kasus ke kejaksaan atau ke pengadilan bisa bergantung pada kesepakatan antara penegak hukum dengan tersangka tentang sejumlah pembayaran. Jika tersangka mampu menyediakan sejumlah uang tertentu, maka perkara bisa dinyatakan tertutup dengan sebuah SP3 dengan alasan tidak cukup bukti, tetapi kalau tersangka tidak mampu untuk membayar, maka perkaranya diteruskan. Malahan atas perkara yang sudah masuk di pengadilan pun besarnya tuntutan jaksa bisa ditawar atau dinilai dengan sejumlah uang. ${ }^{12}$

4. Sering juga mendengar dihambatnya seorang tersangka pelaku suatu tindak kejahatan untuk mendapatkan bantuan hukum atau hambatan untuk berhubungan dengan pengacaranya, sesuatu yang jelas-jelas bertentangan dengan UU No. 14 Tahun 1970 (sebagaimana telah diubah dengan UU No. 35 tahun 1999) maupun UU No. 8 Tahun 1982 tentang Kitab Undang Undang Hukum Acara Pidana (KUHAP). Menurut ketentuan yang diatur di dalam Pasal 35-37 UU No. 14 Tahun 1970 dan dalam Pasal 54 UU No. 8 Tahun 1982 setiap orang yang tersangkut perkara wajib diberikan kesempatan untuk memperoleh bantuan hukum. Ketentuan ini diperkuat oleh Pasal 59 UU tentang KUHAP yang menegaskan bahwa kepada seorang tersangka sejauh ditangkap atau ditahan. wajib diberitahukan hak-haknya, termasuk hak untuk menghubungidan meminta bantuan penasihat hukum.

${ }^{12}$ Laporan utama majalah mingguan Tempo pada edisi 12-18 Juli 1999 dengan topik "Tikus-tikus Kejaksaan Agung." memberikan banyak informasi yang sangat memprihatinkan tentang ini. 
5. Pelanggaran HAM seringkali juga terjadi atas ketentuan Pasal 1 butir 21 dan Pasal 24 KUHAP yang menentukan bahwa penahanan atas tersangka dilakukan apabila ada kekhawatiran dan perkiraan apabila ada kekhawatiran dan perkiraan bahwa tersangka akan melarikan diri, menghilangkan barang bukti, atau menyulitkan pemeriksaan. Dalam praktiknya sering terjadi penuntut umum menahan seorang tersangka meskipun tidak ada alasan yang kuat bagi kemungkinan terjadinya salah satu dari tiga hal tersebut. ${ }^{13}$ Namun tidak jarang pula terjadi ada tersangka.yang selayaknya ditahan ternyata tidak ditahan. ${ }^{14}$

Selain itu pelanggaran-pelanggaran HAM yang terjadi bukan hanya pelang̀garan ațas hak-hak yang sifatnya fisik seperti yang sebagian besar disebutkan di atas tetapi juga terhadap hak-hak politik melalui kekerasankekerasan politik yang dilakukan oleh rezim penguasa di masa lalu dalam penggunaan hak asasi bidang politik, minimal meliputi kekerasan terhadap hak berorganisasi, kekerasan terhadap hak pilih, kekerasan terhadap penyaluran aspirasi, dan kekerasankekerasan lainnya. ${ }^{15}$

Kekerasan terhadap pihak berorganisas $i^{16}$ dilakukaan melalui pembelengguan atas kebebasan rakyat untuk berorganisasi sesuai dengan kehendaknya sendiri. Pemerintah telah melakukan intervensi atas berbagai organisasi kemasyarakatan baik melalui pembatasan-pembatasan tentang asas maupun (secara praktis) dalam menentukan pimpinannya. ${ }^{17}$ Kasus pelanggaran HAM di Tanjung Priok yang sampai saat ini masih menjadi persoalan besar bagi bangsa ini dapat disebut sebagai contoh pelanggaran HAM yang bersumber dari kekerasan terhadap hak berorganisasi. Seperti diketahui kasus tersebut bermula dari penolakan sebagian warga atas kehendak pemerintah untuk menjadikan Pancasila sebagai asas tunggal (satu-satunya) bagi setiap ormas yang boleh hidup di Indonesia. Kebijakan ini ketika itu dirasakan sebagai kebijakan yang melanggar HAM dalam berorganisasi dan karenanya mendapat tantangan keras.

${ }^{13}$ Meskipun begitu mungkin saja penahanan itu benar, tetapi ini adalah contoh bahwa masalah seperti ini sangat mungkin dipolitisasi dan dimanipulasi.

${ }^{14}$ Sementara, sebagai kebalikan dari catatan kaki Nomor 13 , banyak kasus yang berdasarkan rasa keadilan dalam masyarakat tersangkanya harus segera ditahan ternyata tidak ditahan, sebagian diantaranya kemudian ditahan tetapi lebih banyak merupakan respon atas tekanan publik dan berbagai unjuk rasa.

15Lihat dalam Arbi Sanit. "Memahami Kekerasan Politik". Dalam fakultas Hukum UII LKBH. Kekerasan dalam Politik yang Over Acting (sic). Yogyakarta. 1998.

${ }^{16}$ Lihat juga dalam Moh. Mahfud MD. "Mengantisipasi Kekerasan Politik pada Pemilu 1999". Makalah untuk diskusi tentang Kekerasan dalam Pemilu 1999. Diselenggarakan oleh Universitas Atma Jaya. Yogyakarta 2 Maret 1999.

${ }^{17} /$ bid. Juga dalam Moh. Mahfud MD. "Kekuasaan Sebagai Sumber Kekerasan Politik." Makalah pada seminar tentang Negara, Masyarakat dan Kekerasan. Diselenggarakan oleh Fakultas Hukum UII. Yogyakarta 20 Juli 1999. 
Pimpinan ormas yang akan tampil ke pucuk pimpinan juga harus mendapat restu lebih dulu dari pemerintah sehingga tokohtokoh potensial yang kritis dan vokal terhadap pemerintah dihambat untuk maju. Akibatnya tokoh-tokoh ormas yang potensial untuk tampil sebagai pimpinan ormasnya banyak yang terjebak pada upaya mencari dukungan dari pemerintah bukan mencari dukungan dari bawah atau anggota-anggota organisasinya. ${ }^{18}$ Terkait dengan kekerasan berorganisasi yang sebenarnya secara substansial telah diatur di dalam Pasal 28 UUD 1945 pemerintah Orba juga mereduksi HAM rakyat Indonesia dalam membuat organisasi politik melalui penentuan hanya adanya tiga organisasi sosial politik yakni Golongan Karya (Golkar), Partai Persatuan Pembangunan (PPP) dan Partai Demokrasi Indonesia (PDI). Ketentuan yang kemudian dituangkan di dalam UU tentang Parpol dan Golkar ini secara mendasar tentu bertentangan dengan hak untuk berorganisasi karena menutup pintu bagi masyarakat bukan saja untuk membuat parpol baru, tetapi untuk mempersoalkan parpol yang tidak lagi representatif. seharusnya sebuah UU kepartaian hanya memuat syarat-syarat berdin atau bubarnya sebuah parpol yang hanya mendapat dukungan sangat kecil dapat dinyatakan bubar dan jika ada gumpalan aspirasi yang mempunyai dukungan yang sangat besar dapat menampilkan dirinya sebagai parpol baru untuk berkontestasi di dalam pemilihan umum. Namun kekerasan terhadap hak berorganisasi yang dilakukan oleh penguasa telah memaksa rakyat untuk menerima apa yang telah ditetapkan secara final (tentang partai) oleh pemerintah tanpa peluang pembentukan wadah bagi penggumpalan aspirasi baru.

Pemerintah di masa lalu juga telah melakukan kekerasan terhadap hak pilih ${ }^{19} \mathrm{di}$ dalam pemilu yang secara asasi dimiliki oleh setiap warga negara. Memilih yang secara konstutisional merupakan "hak" dalam praktiknya lebih diperlakukan sebagai "kewajiban" dan kewajiban itu harus disalurkan kepada organisasi politik tertentu. Dalam kaitan ini sering terlihat terjadinya politisasi terhadap para pemimpin agama atau para ulama karena mereka dipaksa mengeluarkan fatwa bahwa memilih itu hukumnya wajib, sedangkan tidak memilih atau menjadi golongan putih (golput) itu hukumnya haram. Tidak mengherankan jika kemudian ternyata angka pemberi suara di dalam pemilu sangat besar sebab yang terjadi sebenarnya adalah mobilisasi dan bukan partisipasi. Kekerasan terhadap hak untuk "memilih" diikuti pula dengan kekerasan terhadap hak untuk "dipilih" sebab untuk menjadi anggota MPR, DPR, DPRD, Gubernur, Bupati, Walikota dan sebagainya haruslah lebih dulu melalui dan mendapat persetujuan dari pemerintah baik melalui ketentuan-ketentuan formal maupun melalui rekayasa politik.

${ }^{18} /$ bid.

${ }^{19}$ Arbi Sanit. Loc. Cit. Lihat juga Laporan dan analisis cukup mendalam dalam Hans Thoolen. 1987. Indonesia and the Rule of Law, Twenty Years of New Order Government. London: Frances Printer (Publiser). 
Sejalan dengan itu kekerasan terhadap penyaluran aspirasi politik ${ }^{20}$ juga senantiasa terjadi di dalam proses politik. selain pers yang tidak bebas dan diancam dengan pemberangusan, pemaksaan terhadap anggota lembaga permusyawaratan dan perwakilan rakyat dalam semua level juga terjadi. Mereka senantiasa dipaksa untuk menyetujui kebijakan atau rencana kebijakan pemerintah serta dibawa pada situasi terpaksa untuk memilih calon-calon pejabat mulai dari Presiden dan Pimpinan Lembaga-lembaga Negara sampai pada tingkat bupati dan wali kota bahkan untuk jabatan-jabatan yang lebih rendah dari itu. ${ }^{21}$ Selain melalui penggalangan bagi pemenangan pemilu secara tidak fair sehingga partai pemerintah menguasai suara mayoritas mutlak dan dapat secara efektif menggalang suara dukungan untuk setiap kebijakan atau rencana kebijakan, pemerintah juga melembagakan adanya wakil-wakil yang diangkat tanpa melalui pemilu yang dalam praktiknya juga (harus) selalu memberikan dukungan terhadap pemerintah. Memang adakalanya kita mendengar juga suara kritis dari gedung DPR tetapi semua suara kritis itu hanya terbatas sebagai aksesoris demokratis formal yang dibatasi dengan koridor-koridor tertentu yang bisa ditolelir oleh pemerintah. Padahal penetapan koridor demokrasi oleh pemerintah merupakan sesuatu yang bertentangan dengan demokrasi itu sendiri sebab koridor demokrasi secara implisit telah dimuat di dalam dasar dan konstitusi negara. ${ }^{22}$

Kembali pada salah satu pertanyaan pokok yang telah dikemukakan di atas. Mengapa di negara hukum dan demokrasi seperti Indonesia yang konstitusinya secara nyata menyebutkan pengakuan dan menjanjikan perlindungan atas HAM banyak terjadi pelanggaran HAM yang masih begitu massif?

Secara singkat dapat dikemukakan bahwa pelanggaran yang massif itu terjadi karena tampilnya sistem politik yang tidak demokratis yang kemudian membuka peluang bagi penguasa untuk melakukan pelanggaran HAM melalui celah-celah konstitusi. ${ }^{23}$ Dalam kenyataannya meskipun secara konstitusional negara indonesia menganut demokrasi sebagai asasnya yang fundamental tetapi

${ }^{20}$ Tentang kekerasan atas hak bicara dan menyampaikan aspirasi politik ini dapat diambil contoh darikasus recall dari keanggotaan DPR atas Sri Bintang Pamungkas dan Bambang Warih Kusumo seperti ditulis di dalam Syamsuddin Haris dkk. 1997. Pemilihan umum di Indonesia, Telaah atas Struktur, Proses dan Fungsi. Jakarta:PPW-LIPI. HIm.100-102.

${ }^{21}$ Para calon pejabat itu secara formal-prosedural memang dipilih oleh lembaga yang berwenang tetapi sudah bukan menjadi rahasia bahwa pemilihan itu hasilnya bisa diketahui sebelumnya karena telah diatur lebih dulu bahkan dengan perolehan suara untuk masing-masing calon. Penolakan atau pembangkangan atas skenario yang telah ditentukan oleh pemerintah akan berakibat dilakukannya recall atau pemberhentian.

${ }^{22}$ Koridor atau pembatasan-pembatasan itu misalnya adanya larangan untuk menyinggung $\mathrm{hl}$-hal tertentu yang sebenarnya menjaadi hak publik, seperti mempersoalkan perilaku keluarga istana, di dalam kampanye untuk pemilu.

${ }^{23}$ Tentang celah-celah (kelemahan) konstitusi yang membuka peluang tampilnya pemerintahan yang tidak demokratis lihat di dalam Moh. Mahfud MD. 1999. Amandemen UUD 1945 untuk Reformasi Tata Negara. UII Press. 
prinsip tersebut tidak selalu terwujud dalam praktik kenegaraan. Bahkan hampir seluruh pengalaman dalam menggunakan UUD 1945 pemerintahan yang tampil adalah pemerintahan yang tidak demokratis. ${ }^{24}$ Di bawah konstitusi ini realitas politik menunjukkan bahwa Presiden merupakan pemegang kekuasaan yang paling besar dan menempati puncak piramida yang ada dalam struktur kekuasaan. Presiden yang tampil sebagai primus inter pares dapat melakukan kontrol ketat atas rekruitmen politik di dalam negara termasuk kontrol dalam rekruitmen pejabat negara tertinggi dan tinggi negara seperti anggota MPR/DPR, hakim agung, anggota BPK, dan sebagainya. ${ }^{25}$ Pemegang kekuasaan politik di dalam sistem yang tidak demokratis ini kemudian menggunakan celah-celah UUD 1945 untuk melakukan pelanggaranpelanggaran HAM melalui pembuatan baju hukum atas berbagai kebijakan yang melanggar HAM.

Jawaban singkat tersebut tentunya tidak dapat dipahami secara utuh tanpa elaborasi yang memadai. Untuk itu di bawah ini dikemukakan penelusuran ide HAM berdasar pendekatan socio-legal dan socio-kultural serta hubungannya dengan konstitusi dan penerimaannya di dalam konstitusi yang berlaku di Indonesia.

\section{HAM dan Konstitusi}

Dalam kaitannya dengan konstitusi, ditinjau dari sudut socio-legal dan kultural, sebenarnya pengaturan HAM di dalam UUD 1945 memang membuka peluang bagi terjadinya pelanggaran-pelanggaran oleh penguasa sebab rumusan yang terdapat di dalam UUD 1945 menjadikan HAM sebagai residu kekuasaan negara dan bukan kekuasaan negara yang menjadi residu HAM. ${ }^{26}$ Keharusan perumusan HAM yang bukan menjadi residu kekuasaan di dalam konstitusi itu dapat dilacak dari sejarah HAM dan konstitusi itu sendiri.

Konsep HAM yang muncul dan berkembang di Eropa Barat sejak abad pertengahan sebenarnya tumbuh bersamaan dengan munculnya paham kebangsaan yang mengithami lahirnya negara-negara modern dan sekuler. Gagasan ini dimunculkan sebagai altenatif perombakan atas sistem politik dan ketatanegaraan yang sentralistik, dimana kekuasaan negara terletak di tangan penguasa secara absolut. Absolutisme kekuasaan itu kemudian menimbulkan konflik antara penguasa dan rakyatnya atau antara kekuasaan pemerintah dan kebebasan warga negara yang kemudian melahirkan infra struktur sebagai keniscayaan. ${ }^{27}$ Gerakan kebebasan yang tampil melawan kekuasaan

\footnotetext{
${ }^{24}$ Lihat dalam Moh. Mahfud MD. Pergulatan Politik dan Hukum. Gama Media dan Ford Foundation. 1999. 37-38.

${ }^{25}$ Afan Gaffar. 1999. Politik Indonesia, Transisi Menuju Demokrasi. Yogyakarta: Pustaka Pelajar. Him.

${ }^{26}$ Lihat dalam Moh. Mahfud MD. Amandemen ... Loc. Cit.

${ }^{27}$ Dalam Soetandyo Wignyosoebroto. "Hak-hak Azasi Manusia, Demokrasi dan Pelaksanaannya di Indonesia, Sebuah Tinjauan sosio-kultural dari Prespektif Sejarah." Makalah pada Diskusi Ilmiah. Di PusatAntar Universitas, Studi Sosial, Universitas Gadjah Mada. Yogyakarta. 18 Oktober 1994.
} 
berawal dari meluasnya kekuasaan raja-raja yang semula wilayahnya menyatu dengan kekuasaan gereja (namun kemudian) keluar dari batas territori dan merambah pula pada perluasan urusan (kekuasaan). Merambahnya kekuasaan raja-raja sampai ke luar dari territori yang semula dikuasai bersama dengan gereja menimbulkan pertanyaan tentang legitimasi kekuasaan raja-raja. Kalau semula dasar legitimasinya adalah ketuhanan (teokrasi) karena berbagi tugas dengan gereja dalam territori yang sama maka dengan terjadinya perambahan atas territori yang tidak turut dikuasai gereja itu timbul pertanyaan tentang dasar kekuasaan raja. ${ }^{28}$

Jika raja berkuasa (atas territori di luar kekuasaan bersamanya dengan gereja itu) bukan berdasar teokrasi, lalu atas dasar apakah kekuasaan raja itu? Jawaban yang muncul atas pertanyaan ini adalah demokrasi. Dàsar legitimasi ini mengatakan bahwa raja berkuasa karena rakyat yang menyerahkan penguasaan pengurusan perlindungan HAM kepada raja atau pemerintah tersebut. Raja bukan sebagai: wakil Tuhan atau berkuasa karena Tuhan melainkan karena menerima penyerahan kekuasaan dari rakyat untuk melindungi hak-hak rakyat tersebut. Dengan demikian, maka raja haruslah bertanggungjawab kepada rakyat. ${ }^{29}$ Dari sini kemudian tampak bahwa sebenarnya gagasan perlindungan HAM di dalam negara itu merupakan akibat terjadinya sekularisasi kekuasaan (dari paham teokrasi menjadi demokrasi). ${ }^{30}$

Jika ditelusuri lebih jauh sekularisasi itu sendiri semula timbul karena terjadinya konflik yurisdiksi antara raja (negara) dan Paus (gereja) karena ekspansi raja-raja ke daerah lain di luar territori yang dulunya dikuasai bersama. ${ }^{31}$ Konflik itu terjadi karena Paus juga berusaha menegakkan kekuasaan politiknya atas seluruh penganut agama Kristen tanpa batas dan wilayah kebangsaan. Benih sekularisasi itu telah tumbuh ketika pada tahun 1075 Paus Gregorius VII mengeluarkan pengakuan atas kekuasaan raja dan kaisar melalui sebuah Dictatus Papae untuk memerintah satu territori dalam masalahmasalah keduniawian. Meskipun di dalam dictatus itu dikatakan bahwa kedudukan raja berada di bawah Paus namun pertanyaan mendasar tetap muncul tentang sumber (legitimasi) kekuasaan raja itu. Rasionalisasi yang kemudian muncul adalah teori social contract yang menyebutkan bahwa raja berkuasa karena adanya perjanjian masyarakat yang memberikan kekuasaan untuk mengatur dan menyerasikan kepentingan-kepentingan di antara mereka. Memang tidak semua ahli pikir tentang politik dan hukum sampai pada kesimpulan yang

${ }^{28} /$ bid.

29Dalam Soetandyo Wignyosoebroto. "Konstitusi dan Konstitualisme."Makalah untuk lokakarya Konstitusionalisme untuk kedaulatan Rakyat. Diselenggarakan oleh Konsorsium Reformasi Hukum Nasional KRHN) di Surabaya. Tanggal 15-16 Oktober 1998.

${ }^{30}$ Dalam Moh Mahfud MD. "Berbagai Produk Hukum tentang HAM yang Tampak Tumpang Tindih." Makalah untuk Seminar tentang Implementasi UU HAM. Diselenggarakan oleh ATMA-IKADIN, Kantor Sospol Pemda.Solo, Solo Pos, dan Bakom PKB Kodya Solo. Surakarta tanggal 29 Nopember 1999.

${ }^{31}$ Soetandyo Wignyosoebroto. "Hak-hak.. "Loc. Cit. 
sama bahwa perjanjian masyarakat itu harus melahirkan pemerintahan yang demokratis dan bertanggung jawab kepada rakyatnya. Thomas Hobbes (1588-1679) misalnya, menyebutkan bahwa berdasar perjanjian masyarakat itu, maka pemerintah yang lahir adalah pemerintah yang memiliki kekuasaan mutlak (absolut) karena di dalam perjanjian itu masyarakat telah menyerahkan hak-haknya untuk diurus oleh penguasa. ${ }^{32}$ Tetapi John Locke (1632-1704) dan JJ Rousseau (1712$1778)^{33}$ menyatakan bahwa perjanjian masyarakat itu menuntut lahirnya pemerintahan yang demokratis. Pemerintah yang berkuasa, menurut Locke dan Rousseau, harus bertanggung jawab kepada rakyatnya, sedangkan rakyat harus berani menyatakan kedudukannya sebagai pihak yang memberi mandat dan berhak meminta pertanggungjawaban kepada pemerintah. $\mathrm{Di}$ dalam kontrak sosial itu yang kemudian dituangkan di dalam konstitusi itu terkandung pengertian bahwa tugas utama pemerintah adalah melindungi HAM warganya dan untuk itu kekuasaan pemerintah harus dibatasi baik lingkup urusan maupun jangka waktunya. ${ }^{34}$

Tampaklah bahwa dari sudut socio-kultur dan legal perjalanan HAM itu berkaitan dengan perubahan dasar legitimasi pemerintah dari vox dhei (suara tuhan) dengan teori teokrasinya menjadi vox populi (suara rakyat) dengan teori demokrasinya yang sering disetarakan melalui ungkapan vox populi, vox dhei (suara rakyat adalah suara tuhan). Tampak juga bahwa demokratisasi pertamatama tidak muncul semata-mata karena penolakan atas absolutisme negara melainkan sebagai konsekuensi dari terjadinya sekularisasi kekuasaan yang menghendaki perumusan ulang mengenai keseimbangan hubungan antara rakyat dan penguasa. Dari proses pencarian keseimbangan itulah kemudian timbul gagasan konstitusionalisme yang bermaksud memberikan perlindungan bagi warga negara dalam berhadapan dengan pemerintahnya.

Penelusuran socio-legal dan kultural di atas memberi penegasan bahwa konstitusi bukan merupakan fungsi residual HAM dari kekuasaan negara dan pemerintah melainkan, sebaliknya, merupakan fungsi residual kekuasaan dari kebebasan dan HAM. Artinya konstitusi itu sebenarnya tidak boleh memberi pembatasan atas HAM atau menjadikannya sebagai sisa dari kekuasaan pemerintah semata, sebaliknya kekuasaan pemerintah harus dibatasi oleh konstitusi agar HAM warganya tidak dilanggar baik oleh pemerintah maupun oleh sesama warganya.

\section{Elaborasi Konstitusionalisme}

Penjelajahan singkat tentang latar belakang munculnya konstitusi yang berkaitan dengan teori perjanjian masyarakat kemudian memberi arti bahwa konstitusi merupakan

\footnotetext{
32Dapat dibaca misalnya di dalam Deliar Noer. 1998. Pemikiran Politik di Negari Barat. Cet. Ill. Bandung: Mizan. HIm. 101-115.

${ }^{33}$ lbid.

${ }^{34}$ Lihat dalam Naoki Kobayashi. "Different Concepts of Modern Constitution." Dalam Senshu Hongaku Ronshu. 39 (Bassatsu). 1984. HIm. 1-31.
} 
aturan dasar ketatanegaraan yang dibuat oleh masyarakat guna memberikan arah dalam penyelenggaraan pemerintahan negara. Konstitusi merupakan realisasi dari demokrasi yang berisi kesepakatan tentang pembatasan kekuasaan negara oleh rakyat dan bukan sebaliknya, kebebasan ditentukan oleh penguasa.

Sebenarnya sangat banyak pakar yang memberikan pandangan ilmiahnya tentang konstitusi, namun esensinya sama. CF Strong James Bryace dan Henc Marseveen misalnya, ${ }^{35}$ mengatakan bahwa konstitusi merupakan ketentuan yang memberikan pengaturan dan menentukan fungsi bagi lembaga-lembaga negara agar tidak terjadi pelanggaran atas HAM. CF Strong dalam kaitan ini mengatakan bahwa elemen penting dalam konstitusi adalah "how the varies agencies are organized, what power is to be enthrusted to those agencies" dan "in manner such as power is to be exercised" ${ }^{36}$ Pakar lain seperti Loewenstein, Herman Finer dan Friedrich mengatakan bahwa konstitusi merupakan sarana pengendalian kekuasaan, sedangkan KC Wheare, pakar yang banyak dirujuk dalam studi tentang konstitusi, mengatakan bahwa "constitution is used to describe the whole system of goverment of a country, the collection of rule which establish and regulate or govern the goverment. ${ }^{37}$
Dengan demikian dapat dikenali dengan mudah bahwa konstitusionalisme, minimal mencakup dua hal yang sangat esensial yakni: Pertama, konsepsi negara hukum yang menyatakan bahwa secara universal kewibawaan hukum haruslah mengatasi kekuasaan pemerintah yang berarti pula bahwa hukum harus mampu mengontrol dan mengendalikan politik; Kedua, konsepsi hakhak sipil warga negara yang menggariskan adanya kebebasan warga negara di bawah jaminan konstitusi sekaligus adanya pembatasan kekuasaan negara yang dasar legitimasinya hanya dapat diperoleh dari konstitusi. $^{38}$ Implementasi atas muatan konstitusionalisme tersebut harus melahirkan pemerintahan yang memiliki ciri-ciri sebagai berikut:

1. Kekuasaan publik hanya dapat dilegitimasi menurut ketentuan konstitusi.

2. Pelaksanaan kedaulatan rakyat (melalui penwakilan) harus digunakan berdasar prinsip "universal and equal suffrage" yang disertai dengan pengangkatan pejabat eksekutif melalui pemilihan yang demokratis.

3. Pemisahan atas pembagian kekuasaan yang disertai dengan batas-batas wewenang masing-masing pemegang kekuasaan.

${ }^{35}$ Konsorsium Reformasi hukum Nasional (Tim). "Konstitusi yang Ideal, Suatu Kajian Kritis terhadap Konstitusi." Makalah untuk lokakarya Konstitusionalisme untuk Kedaulatan Rakyat yang diselenggarakan oleh Konsorsium Reformasi Hukum Nasional (KRHN). Surabaya tanggal 15-16 Oktober 1998.

${ }^{38} \mathrm{CF}$ Strong. 1952. "Modern. Political Constitutions." An Introduction to the Comparative Study of Their History and Existing Form. London: Sidgwick \& Jackson Ltd. 1952.

${ }^{37} \mathrm{KC}$ Where. 1951. Modern Constitutions. London: Oxford University Press. 1951.

${ }^{38}$ Soetandyo Wignyosoebroto. "Konstitusi.. " Loc. Cit. 
4. Kekuasaan kehakiman yang mandiriyang dapat menegakkan hukum dan keadilan baik terhadap rakyat maupun terhadap penguasa.

5. Adanya sistem kontrol terhadap militer dan kepolisian untuk menegakkan hukum dan menghormati hak-hak rakyat.

6. Adanya jaminan perlindungan atas HAM $^{39}$

\section{Pewadahan di dalam Konstitusi Indonesia}

Untuk mencari jawaban dari sudut politik hukum atas masalah-masalah pelanggaran HAM yang secara massif sering muncul di Indonesia, maka perlu dilihat respon atau pewadahan konstitusi Indonesia atas pesan socio-legal dan kultural serta cakupan esensial mengenai konstitusionalisme.

Kenyataan bahwa pelanggaran HAM banyak terjadi secara besar-besaran terutama selama masa berlakunya UUD 1945 telah menimbulkan pertanyaan tentang sikap konstitusi tersebut atas HAM. Ada yang berpendapàt bahwa UUD 1945 sebenarnya tidak banyak memberi perhatian pada HAM. Bahkan ada yang mengatakan bahwa UUD 1945 tidak berbicara apapun tentang HAM $^{40}$ kecuali dalam dua hal yakni sila kedua Pancasila yang meletakkan prinsip "kemanusiaan yang adil dan beradab" dan Pasal 29 UUD 1945 yang menderivasikan prinsip kemerdekaan tiap penduduk untuk memeluk agama dan beribadah. Pewadahan gagasan tentang perlindungan hak-hak rakyat di dalam UUD 1945 lebih merupakan pewadahan atas gagasan Hak Asasi Warga Negara (HAW) yang sebenarnya merupakan penerimaan yang sifatnya partikularistik atas HAM. Istilah HAM partikularistik biasanya diartikan sebagai HAM yang penerimaannya dan pelaksanaannya harus disesuaikan dengan kondisi khusus Indonesia, bukan diterima begitu saja sebagai konsep yang siap pakai. Bahkan dikatakan bahwa alinea pertama Pembukaan UUD 1945 yang menyatakan bahwa kemerdekaan adalah hak segala bangsa masih dapat dinilai partikularistik karena pernyataan itu hanya dijadikan alasan untuk kemerdekaan bagi bangsa Indonesia ${ }^{41}$ dan bukan dukungan atas gagasan HAM yang universal. pasal-pasal lain yang selama ini dianggap sebagai jaminan perlindungan bagi HAM seperti Pasal 27 dan Pasal 28 UUD 1945 sebenarnya lebih merupakan pengakuan atas hak asasi warga negara (HAW) yang partikularistik. Itu pun dalam konstitusi masih dikatakan (akan) diatur dengan Undang-undang yang berarti meletakkan konstitusi sebagai fungsi residu HAW dari kekuasaan negara.

Meskipun dalam pengertian sehari-hari tampaknya tidak banyak dipersoalkan, tetapi secara akademis sebenarnya ada perbedaan antara HAM dan HAW sebab jika HAM mendasarkan diri pada paham bahwa secara

${ }^{39}$ Bambang Widjoyanto. "Reformasi Konstitusi, Sebuah Keniscayaan." Dalam tabloid DETAK 9 Oktöber 1998.

${ }^{40}$ Soetandyo Wignyosoebroto. "Hak-hak.........." Loc. Cit.

${ }^{41}$ ibid. Juga dalam Moh. mahfud MD. "UU Politik, Keormasan dan Instrumentasi Hak Azasi Manusia." Dalam Jurnal Hukum No. 10Nol. 5/1998. 
kodrati manusia itu mempunyai hak-hak bawaan yang tidak dapat dipindahkan atau diambil oleh siapapun, maka HAW hanya mungkin diperoleh jika seseorang menjadi warga dari suatu negara. Sementara itu menurut Pasal 26 UUD 1945 status kewarganegaraan hanya dapat diperoleh oleh seseorang setelah memenuhi syarat-syarat yang ditentukan oleh undang-undang, sedangkan undang-undang itu sendiri menurut UUD 1945 (seperti yang diatur dalam Pasal 5 dan Pasal 21) dibentuk oleh Presiden dengan persetujuan DPR.42 Jadi jika dirunut dari Pasal 26 tentang kewarganegaraan dan Pasal 5 serta Pasal 21 UUD 1945 tentang hak pembuatan UU maka HAW itu bukan hak kodrati (bawaan) tetapi hak yang diberikan oleh pemerintah melalui UU. Ini jelas tidak sejalan dengan maksud atau filosofi sebagaimana digambarkan dari jelajah sociolegal dan kultural yang menyebutkan bahwa konstitusionalisme justru bermaksud menyisakan hak-hak dasar manusia yang dapat diberikan kepada pemerintah dan bukan menyisakan kekuasaan pemerintah yang dapat diberikan kepada rakyat.

Reduksi gagasan dari HAM menjadi HAW itu pun menurut Soetandyo, cakupannya ternyata masih tidak memadai karena hanya ada dua pasal di dalam UUD 1945 yang secara eksplisit berbicara tentang HAW yakni Pasal 27 ayat (2) dan Pasal 31 . Pasal 27 ayat (2) menyatakan bahwa tiap-tiap warga negara berhak atas pekerjaan dan penghidupan yang layak, sedangkan Pasal 31 menyatakan bahwa tiap-tiap warga negara berhak mendapat pengajaran. Pasal-pasal lain yang terkait dengan HAW seperti hak untuk berserikat dan menyatakan pendapat (Pasal 28) tidak secara eksplisit disebut sebagai hak warga negara melainkan dinyatakan akan diatur dengan UU.

Formulasi konstitusi yang partikularistik dan secara eksplisit menyerahkan hal-hal penting dalam bidang HAM (HAW) untuk diatur dengan undang-undang dalam kenyataannya telah menimbulkan masalah besar bagi bangsa Indonesia. Melalui sistem politik executive heavy yang juga dianut oleh UUD 1945 pemerintah telah melakukan pembatasan secara ketat atas penggunaan HAM di Indonesia dengan menggunakan atribusi dan delegasi kewenangan yang dimilikinya. Ketika membuat UU untuk merealisasikan pesanpesan tentang HAM atau HAW itu ternyata pemerintah telah membuka pintu bagi terjadinya pelanggaran HAM itu sendiri. Hal itu tampak misalnya dari UU tentang Pokokpokok Pers yang membelenggu kebebasan pers melalui ancaman pemberangusan, UU Kepartaian (Parpol dan Golkar) yang hanya membatasi orsospol tertentu yang bisa mengikuti kontestan politik serta tidak membuka pintu bagi gumpalan aspirasi baru, tentang Pemilu yang sangat konservatif dalan membuka peluang terjadinya kecurangan oleh pemerintah dalam rantaj-rantai proses pelaksanaannya ${ }^{43}$ UU tentang MPR/DPR/ DPRD yang membuka peluang bagi

${ }^{42}$ Pasal 5 dan Pasal 21 UUD 1945 telah diamandemen dan diubah melalui Perubahan Pertama UUD 1945 pada sidang Umum MPR tahun 1999 tetapi perubahannya lebih bersifat semantik, tidak substantif.

«Lihat dalam Moh. Mahfud MD. 1998. Politik Hukum di Indonesia. Jakarta: LP3ES. Juga dalam Syamsuddin Haris dkk. Op.Cit HIm. 177-182. 
pemerintah untuk melakukan intervensi, screening dan recall (oleh pimpinan orsospol) sehingga wakil rakyat yang boleh ada di parlemen hanya mereka yang diyakini sejalan dengan kehendak politik pemerintah, ${ }^{44} \mathrm{UU}$ tentang keormasan yang selain membelenggu dengan asas tunggal juga membuka peluang bagi pemerintah untuk melakukan kooptasi, sehingga semua ormas menjadi bagian dari jaringan korporatisme negara dan sebagainya.

Dengan demikian jika formulasi UUD 1945 tentang HAM dan. HAW dikaitkan dengan terjadinya berbagai pelanggaran HAM maka tampak bahwa selain dilakukan dengan terang-terangan secara melanggar hukum pelanggaran HAM itu juga dilakukan melalui prosedur yang secara "formalitas" benar karena untuk berbagai pelanggaran HAM itu telah dibuatkan UU lebih dulu untuk membenarkannya. Pertanyaannya yang kemudian timbul menyusul jawaban atas pertanyaan sebelumnya ialah mengapa para pendiri negara (founding fathers) yang menyusun UUD 1945 ini membuat formulasi yang banyak membuka peluang bagi terjadinya pelanggaran HAM.

\section{Kompromi Para Pendiri Negara}

Pertanyaan tentang mengapa formulasi atau politik hukum yang digariskan oleh UUD
1945 tentang hak asasi manusia cenderung partikularistik dan membuka peluang bagi terjadinya dominasi (dan reduksi oleh) negara dalam pelaksanaannya dapat dipahami dari sejarah rumusan UUD 1945 oleh para pendiri negara (founding fathers) yang ketika itu bergabung dalam Badan Penyidik Usahausaha Persiapan Kemerdekaan Indonesia (BPUPKI), sebuah panitia perancang konstitusi yang dibentuk atas usaha dan anjuran pemerintah penjajahan Jepang untuk menyongsong kemerdekaan Indonesia yang ketika itu dijanjikan akan segera diberikan oleh pemerintah Jepang. ${ }^{45}$ Pemahaman dan sejarah perumusan atas kalimat-kalimat konstitusi ini penting karena di sana dapat diketahui berbagai pemikiran yang mendasar konstitusi bahkan juga segala kondisi dan konflik yang melahirkan konstitusi tersebut, seperti yang dikatakan oleh Corwin dan Peltason:

"By placing the constitution in the context of history, we can come learn of the conditions and conflict that produced it and continued give it meaning ${ }^{\text {ns6 }}$

Ketika itu rumusan konstitusi tentang HAM memang merupakan hasil kompromi dari dua pendapat yang berlainan yakni Soekarno dan Soepomo pada satu pihak serta Hatta dan Yamin pada pihak lain. ${ }^{47}$ Soekarno dan

4Lihat kembali Syamsuddin Haris seperti disinggung dalam catatan kaki nomor 20.

${ }^{45}$ Tentang ini dapat dilihat misalnya dalam Gerge Mc Truman Kahin. 1952. Nationalisme Revolution in Indonesia. New York: Cornell University Press, Ithaca. 1952.

${ }^{46}$ Edward S Corwin dan JW Peltason. 1967. Understanding the Constitution. New York, Chicago, San Fransisco, Toronto, London: Rinehart and Wilson Inc. HIm. 1.

${ }^{47}$ Buku yang sering menjadi rujukan utama tentang sejarah perumusan konstitusi di Indonesia adalah karya Muhammad Yamin. Naskah Persiapan Undang Undang Dasar 1945. Cet. I Jilid I. Yayasan Penerbit Siguntang. 1959. Him. 287-306. 
Soepomo menolak masuknya ketentuan tentang HAM di dalam konstitusi karena menurut mereka Indonesia akan dibangun berdasar paham negara kekeluargaan dan bukan negara yang didasarkan pada individualisme, sedangkan Hatta dan Yamin mengusulkan dimasukkannya ketentuan HAM di dalam konstitusi guna menghindari penyalahgunaan kekuasaan yang melanggar hak-hak rakyat oleh para penyelenggara negara. Di depan Sidang BPUPKI Soekarno mengemukakan alasannya dengan tegas ketika mengatakan:

"...........buanglah sama sekali paham individualisme itu, janganlah dimasukkan ke dalam undang undang dasar kita yang dinamakan 'rights of the citizen' sebagai yang dianjurkan oleh republik Perancis itu adanya, kita menghendaki keadilan sosial. ${ }^{\text {n48 }}$

Dari pernyataan itu tampak bahwa Soekarno tidak menghendaki masuknya HAM ke dalam konstitusi seperti yang ada di Perancis karena 'right of citizen' tidak bisa diterima di negara yang hendak membangun keadilan sosial di kalangan rakyatnya. Soepomo memperkuat apa yang dikemukakakan oleh Soekarno itu ketika menyatakan bahwa:

"... dalam undang undang dasar kita tidak bisa memasukkan pasal-pasal yang tidak berdasarkan aliran kekeluargaan, meskipun sebenarnya kita ingin sekali memasukkan... ${ }^{\text {m99 }}$

Menurut Soepomo tidak perlu memasukkan pasal-pasal tentang Hak Asasi ke dalam Undang-Undang Dasar karena telah dipilih untuk mendirikan negara yang berkedaulatan rakyat.50 Jadi bagi Soekarno dan Soepomo pencantuman pasal-pasal hak asasi manusia di dalam undang undang dasar akan berlawanan dengan kehendak membangun keadilan sosial dan kedaulatan rakyat.

Tetapi berbeda dengan itu dua anggota BPUPKI yang juga sangat menonjol. Hatta dan Yamin, justru meminta agar di dalam undang undang dasar dimasukkan pasal-pasal tentang hak asasi agar rakyat tidak takut mengelurkan pendapatnya. Hatta mengatakan:

‘...ada baiknya dalam salah satu pasal yang mengenai warga negara disebutkan juga di sebelah hak yang sudah diberikan kepadanya misalnya tiap-tiap warga negara jangan takut mengeluarkan suaranya... . $^{\text {si }}$

Yamin memberi penegasan juga ketika mengemukakan bahwa:

"... supaya aturan kemerdekaan warga negara dimasukkan dalam Undang Undang Dasar seluas-luasnya. Saya menolak segala alasan-alasan yang dimajukan untuk tidak memasukkannya... ${ }^{\text {n2 }}$

\footnotetext{
48/bid.

$49 /$ bid.

solbid.

silbid.

s2/bid.
} 
Perdebatan itu kemudian melahirkan kompromi yakni dimasukkannya beberapa pasal tentang HAM tetapi dengan nuansa partikularistik dalam arti lebih ditujukan pada keperluan spesifik warga negara Indonesia dan dengan formulasi yang memberi kekuasaan pengaturan oleh negara melalui undang undang.

Dari penelusuran sejarah mengenai prinsip dan konsepsi HAM dengan segala perkembangannya di dalam pemikiran politik serta dari pewadahan konstitusi Indonesia, UUD 1945, ternyata bahwa pelanggaran HAM itu dilakukan melalui politik hukum yang digariskan oleh UUD 1945 tentang HAM yang merupakan hasil kompromi antara yang menerima dan yang menolak masuknya konsepsi HAM. Penerimaan dan formulasi yang kompromis telah membuka peluang bagi pemerintah (yang dalam praktiknya sangat dominan) untuk membuat dan mengatur berbagai masalah HAM dengan UU, terutama yang berkaitan dengan Pasal 28 tentang kemerdekaan berserikat, berkumpul dan menyatakan pendapat. Dalam kenyataannya pemerintah memang banyak membuat UU yang menyangkut HAM yang membuka pintu dan berisi pembenaran bagi pemerintah untuk melakukan pelanggaran-pelanggaran atas HAM itu sendiri seperti UU yang berkaitan dengan pers, keormasan, kepartaian, pemilu dan lembaga perwakilan. Pihak pemerintah selalu beralasan bahwa semua UU itu telah dibuat secara benar dan konstitusional sebab pembuatannya didasarkan pada atribusi kewenangan yang diberikan oleh UUD 1945 itu sendiri. Dan memang dari sudut "formalitas prosedural" yang ditentukan oleh konstitusi pembuatan berbagai undang undang itu sah tetapi yang menjadi persoalan adalah esensinya yang ternyata bertentangan dengan ajaran konstitusionalisme.

Sebenarnya pembuatan berbagai UU tentang HAM itu tidaklah terlalu menjadi masalah dan tidak akan berbenturan dengan maksud substansial konstitusionalisme seandainya sistem politik yang melahirkannya adalah sistem yang demokratis. Tetapi persoalannya adalah UUD 1945 itu sendiri yang tidak mampu melahirkan sistem politik dan pemerintahan yang demokratis karena memang meletakkan dasar bagi sistem yang executive heavy, suatu sistem yang meletakkan porsi kekuasaan terbesar di tangan Presiden..$^{53}$ UUD 1945 tidk menyediakan mekanisme yang ketat tentang keseimbangan kekuatan untuk saling mengawasi (chek and balances) antara lembaga-lembaga negara yang dibentuk sehingga Presiden senantiasa dapat melakukan akumulasi atas kekuasaannya secara terus menerus. Pada era Orde Baru Presiden yang secara yuridis konstitusional merupakan separuh dari kekuasaan legislatif secara praktis menjadi penentu seluruh proses legislasi karena dengan kekuatan politiknya Presiden telah memformat DPR sehingga terdiri dari anggota-anggota yang harus selalu mendukungnya. Bahkan secara praktis sebenarnya Presiden telah menjadi kepala legislatif karena sebuah produk RUU baru bisa sah dan berlaku kalau sudah ditandatangani

53Moh. Mahfud MD. Amandemen .... Loc. Cit. 
dan diundangkan oleh Presiden. Melalui kekuatan politik dan atribusi dari UUD 1945 pula Presiden membuat berbagai UU yang menyebabkan lembaga-lembaga negara di luar presiden menjadi lumpuh jika berhadapan dengan Presiden.

\section{Pergeseran Konsep Negara Hukum}

Kenyataan bahwa tindakan-tindakan pemerintah yang melanggar prinsip konstitusionalisme, terutama melanggar HAM, selalu bisa dibenarkan secara formal konstitusional karena diberi baju hukum berupa UU atau peraturan perundang undangan lainnya telah menyebabkan terjadinya pergeseran prinsip dan konsesi dari negara hukum menjadi negara undangundang. Inilah yang banyak terjadi di Indonesia, yakni berubahnya negara hukum menjadi negara undang-undang yang meletakkan undang-undang yang dibuat oleh pemerintah sebagai ukuran kebenaran. Di dalam negara undang undang yang seperti ini ukuran-ukuran kebenaran bukan lagi rasa keadilan dan kepatutan dengan sukma etika yang tinggi melainkan kalimat-kalimat undang-undang yang pembuatannya dilakukan melalui rekayasa bagi kepentingan pemerintah. $\mathrm{Di}$ dalam negara undang undang yang seperti ini setiap tindakan pemerintah yang tidak adil diberi pembenaran dengan pembuatan UU melalui penggunaan atribusi kewenangan, sehingga hukum ditempatkan sebagai alat justifikasi dengan watak "positivistinstrumentalistik". Hukum yang berwatak positivist-instrumentalistik adalah hukum yang dijadikan instrumen untuk membenarkan apa yang akan atau telah dilakukan oleh penguasa: ${ }^{54}$ Dengan sendirinya legitimasi yang dimiliki pemerintah dalam menyelenggarakan kekuasaan juga lebih merupakan legitimasi formal atau legitimsi yang penuh kontradiksi-kontradiksi. Berbagai pelanggaran dan kontradiksi di Indonesia menjadi niscaya karena di dalam rezim yang legitimasinya hanya sekedar formalitas memang penuh dengan kontradiksi dan membuka peluang bagi terjadinya berbagai krisis. ${ }^{55}$

Selain itu meskipun negara Indonesia telah memiliki konstitusi yang dalam bentuk tertulisnya adalah UUD 1945, tetapi rekaman sejarah perjalanan politik dan hukum telah memancing timbulnya pertanyaan tentang ada atau tidaknya pemerintahan konstitusional di Indonesia. Pertanyaan semacam ini timbul karena dalam artinya yang benar pemerintahan yang konstitusional itu bukan hanya pemerintahan yang didasarkan pada konstitusi atau bukan diukur dari ada atau tidaknya konstitusi di negara yang bersangkutan melainkan pertama-tama harus diukur dari ada atau tidaknya esensi konstitusionalisme di dalam konstitusi atau undang-undang dasar yang dipergunakan, untuk kemudian diukur lagi implementasinya

${ }^{54}$ Moh. Mahfud MD. Hukum dan ... Loc. Cit. Lihat juga dalam John Henry Marrymann 1969. The Civil Law Tradition. California: Stanford University Press.

${ }^{55}$ Lihat dalam Mutiah Alagappa. 1995. Political Legitimacy in Southeast Asia, the Quest for moral Authority. California: Stanford University Press. 
di dalam praktik pemerintahan. Pemerintahan Konstitusional adalah pemerintahan di suatu negara yang memiliki konstitusi yang baik dan pemerintahnya melaksanakan konstitusi yang baik itu di dalam praktik pemerintahannya. Suatu pemerintahan yang berdasarkan pada konstitusi tetapi konstitusinya tidak memuat esensi konstitusionalisme, dalam arti tidak memberi jaminan yang sungguh-sungguh atas perlindungan HAM melalui distribusi kekuasaan yang seimbang dan demokratis bukanlah pemerintahan konstitusional. ${ }^{56}$ Suatu negara yang memiliki undang undang dasar tetapi undang undang dasar tersebut membuka peluang bagi terjadinya sistem politik yang tidak demokratis melalui penafsiranpenafsiran sepihak oleh penguasa bukanlah pemerintahan yang konstitusional. Jadi meskipun pemerintahan itu telah dilaksanakan sesuai dengan konstitusi yang ada, tetapi jika konstitusi yang ada itu tidak sejalan dengan konstitusionalisme, maka pemerintahan itu bukanlah pemerintahan konstitusional. Dengan demikian, negara yang secara resmi memiliki konstitusi belum tentu melahirkan pemerintahan yang konstitusional. ${ }^{57}$

Dalam konteks inilah dilihat bahwa di bawah UUD 1945 pemerintah konstitusional tidak muncul dengan baik sebab selama berlakunya UUD 1945 pemerintahan yang demokratis tidak muncul dan pelanggaran HAM terjadi secara massif. Memang benar bahwa dengan adanya UUD 1945 berarti Indonesia secara formal adalah negara konstitusional, tetapi karena UUD ini tidak mengelaborasi konstitusionalisme secara ketat dan mudah dimanipulasi melalui formalitas-formalitas, maka yang akan muncul bukanlah pemerintahan konstitusional.

\section{Penggarisan Politik Hukum Indonesia}

Gerakan reformasi yang berhasil menjatuhkan rezim Orde Baru sebenarnya didorong oleh keinginan pengalaman dimana pemerintahan kita tidak demokratis dan penuh dengan korupsi, kolusi, dan nepotisdme (KKN) serta penuh dengan pelanggaran HAM. Pelanggaran itu biasanya dilakukan dengan memberi baju hukum lebih dulu sehingga secara formal tidak dapat disalahkan, sebab pemberian baju hukum itu sendiri dilakukan dengan menggunakan kewenangan yang diberikan oleh UUD 1945. Yang dilakukan dalam konteks ini adalah memanipulasi kewenangan yang diberikan UUD. Itulah sebabnya reformasi konstitusi yang dalam bahasa populernya disebut sebagai amandemen atas UUD 1945 dijadikan sebagai salah satu dari agenda reformasi menuju Indonesia baru di samping agendaagenda lainnya seperti pengadilan atas KKN, perubahan UU bidang politik, pencabutan dwifungsi militer, otonomi daerah yang seluasluasnya, dan lain-lain yang dari sudut formal sebagian di antaranya telah mulai direalisasikan.

Berkaitan dengan pelanggaran HAM maka amandemen UUD 1945 yang kini terus

${ }^{56}$ Adnan Buyung Nasution. 1992. The Aspiration for Constitusional Government in Indonesia, a Socio-Legal Study of the Indonesian Konstituante 1956-1959. Jakarta: Pustaka Sinar Harapan. HIm. 118. ${ }^{57}$ Demokrasi yang seperti ini juga disebut sebagai demokrasi formal atau demokrasi normtif yang biasanya tidak selalu sama dengan demokrasi empirisnya. Lihat juga dalam Afan Gaffar. Op. Cit. HIm. 3. 
berproses untuk tahap berikutnya $a^{58}$ sangat penting karena seperti terlihat dari uraian diatas penyebab terjadinya pelanggaran HAM itu adalah sistem politik yang tidak demokratis sedangkan sistem yang tidak demokratis itu dibangun oleh penguasa dengan menggunakan alasan-alasan yang diambil dari UUD 1945 sendiri bahkan sering dikatakan justru untuk melaksanakan pesan UUD 1945.

Meskipun demikian pembicaraan tentang politik hukum dalam penegakan HAM pada saat ini tidak dapat mencukupkan diri pada politik hukum dalam kaitan dengan amandemen UUD 1945 semata karena di depan ada masalah kongkrit yang harus diselesaikan juga dalam waktu pendek. $\mathrm{Di}$ depan kita ada tumpukan kasus yang harus segera diselesaikan seperti kasus pelanggaran HAM di Tanjung priok yang masih memancing timbulnya aksi kekerasan, kasus pelanggaran HAM di Aceh, dan sebagainya. pelaksanaan agenda reformasi dalam politik hukum HAM dan bidang. lainnya ke depan akan sangat dipengaruhi oleh penyelesaian atas kasus pelanggaran HAM dan dalam bidang lainnya ke depan akan sangat dipengaruhi oleh penyelesaian atas kasus pelanggaran HAM berat dan berbagai $K K N$ di masa lalu yang kini sedang ditangani oleh pemerintah melalui pergulatan yang sangat sengit.
Berdasarkan alasan-alasantersebut maka penggarisan politik hukum HAM di Indonesia perlu dibedakan ke dalam agenda kerja jangka panjang dan jangka pendek.

\section{Politik Jangka Panjang}

Seperti telah dikemukakan di atas, oleh karena pelanggaran HAM berat lebih banyak disebabkan oleh sistem politik yang tidak demokratis yang dibangun dengan menggunakan alasan-alasan UUD 1945 maka untuk jangka panjang politik hukum HAM harus memberi landasan konstitusional bagi keharusan munculnya sistem politik yang demokratis melalui perubahan atau amandemen atas UUD 1945. Amandemen disini diartikan sebagai perubahan dalam arti yang umum, bukan dalam arti khusus seperti di Amerika Serikat yang mengartikan amandemen sebagai perubahan untuk satu pasal, sehingga setiap perubahan atas pasal tertentu dibuatkan amandemen (lampiran) konstitusi sendiri. Pengertian umum ini perlu dikemukakan agar tidak selalu terjebak pada perubahan tentang istilah yang ada di dalam teori atau ada di negara tertentu, sebab kita pun berhak mengikuti atau tidak mengikuti arti tertentu yang berlaku di dalam teori atau di suatu negara atau memberi arti tersendiri bagi isitilah-istilah yang memiliki banyak arti. ${ }^{59}$

${ }^{58}$ Tahap yang pertama telah dilakukan pada Sidang Umum tahun 1999 sedangkan tahap berikutnya dilakukan pada Sidang Tahunan MPR tahun 2000. Perbaikan secara bertahap tampaknya akan dan terus dilakukan.

${ }^{59} \mathrm{Di}$ dalam wacana adakalanya masih dipersoalkan penggunaan amandemen dengan merujuk pada apa yang berlaku di Amerika Serikat. Sebenarnya suatu program hukum itu tidak harus mengikuti arti di dalam teori atau di negara tertentu, sebab setiap produk hukum yang disahkan oleh lembaga yang berwenang itu sudah berlaku sebagai hukum tanpa harus dipersoalkan apa dasar teorinya dan sesuai dengan yang berlaku di negaralain. 
Dalam pengertian yang seperti ini kita bersyukur bahwa sakralisasi, bahkan (meminjam istilah Syafi'i Ma'arif pemberhalaan, atas UUD 1945 telah dapat di hilangkan oleh gejolak gerakan reformasi sehingga Sidang Umum MPR tahun 1999 telah berhasil membuat perubahan pertama UUD 1945 yang menyangkut sembilan pasal ${ }^{60}$ dan Sidang Tahunan MPR 2000 telah berhasil membuat perubahan kedua.

Secara substansial, jika dikaitkan dengan konstitusionalisme, maka perubahan pertama UUD 1945 dapat diartikan belum berarti banyak bahkan untuk hal-hal yang sebenarnya penting lebih merupakan perubahan sematik. Tetapi yang sangat penting dari perubahan pertama itu bukan isinya melainkan terjadinya perubahan itu sendiri, sebab dengan runtuhnya sakralisasi dan pemberhalaan maka perubahan-perubahan berikutnya yang lebih bermakna substansial dapat lebih mudah dilakukan.

Seharusnya untuk tahap-tahap perubahan berikutnya perubahan UUD kita mengarah pada elaborasi konstitusionalisme secara ketat dengan membuat distribusi dan pembatasan kekuasaan secara seimbang utuk setiap lembaga negara yang disertai mekanisme checks and balances. Pembatasan kekuasan harus tegas mencakup lingkup urusan dan batas waktu, sedangkan formulasi tentang perlindungan HAM harus menutup pintu bagi dilakukannya pembalikan dari kekuasaan sebagai residu HAM menjadi HAM sebagai residu kekuasaan seperti yang terjadi selama ini. Ini berarti atribusi dan delegasi kewenangan kepada pemerintah untuk membuat lagi UU atau peraturan perundang-undangan lainnya yang berkaitan dengan HAM harus sangat dibatasi. UUD yang diamandemen nanti sedapat mungkin mengakomodasi sikap resmi tentang penerimaan atas konvensikonvensi internasional tentang HAM atau memberi dorongan yang tegas bagi upaya untuk meratifikasi berbagai konvensi tersebut. ${ }^{\text {or }}$ Hanya saja agak disayangkan bahwa momentum untuk melakukan perubahan secara baik melalui Sidang Tahunan MPR 2000 telah dilewatkan oleh MPR, terbukti selain menawarkan rancangan amandemen (perubahan kedua) yang konstruksinya agak kacau, Sidang Tahunan juga tidak mampu menyelesaikan masalahmasalah mendasar yang sebenarnya telah diagendakan untuk dibahas seperti tentang MPR, pemilihan Presiden, Mahkamah Konstitusi, dan sebagainya. Ini terjadi karena banyak anggota MPR yang tidak mampu mensterilkan dirinya dari kepentingan politik sesaat padahal setiap pembaruan konstitusi haruslah diproyeksikan untuk jangka panjang bagi kepentingan negara dan bangsa secara keseluruhan.

Dalam kaitan dengan proses perubahan yang sungguh-sungguh serta masih terbukanya peluang bagi amandemen untuk dua tahun mendatang maka ada baiknya dipertimbangkan keputusan Forum Rembuk

\footnotetext{
${ }^{60}$ Pasal-pasal yang telah diamandemen adalah Pasal $5,7,9,13,14,15,17,20$, dan 21.

${ }^{61}$ Salah satu persoalan yang juga muncul dalam politik hukum tentang HAM adalah lambatnya negara kita meratifikasi berbagai konvensi internasional tentang HAM. Kontroversi tentang HAM universal dan HAM partikularistik atau konsepsi HAM generasi pertama dan generasi kedua tampaknya masih persoalan.
} 
Nasional (FRN) yang berakhir awal Juli 2000 di Denpasar yang mengusulkan dibentuknya Dewan Perancang Konstitusi. Usul ini menghendaki agar perubahan UUD tidak dimonopoli oleh MPR melainkan diberikan pada satu komite yang netral dan steril dari kepentingan-kepentingan politik sesaat serta terdiri dari para ahli yang memiliki integritas dalam bidangnya. Gagasan tentang sebuah komisi yang netral ini sangat penting karena ada tengarai, sedikitnya kekhawatiran, bahwa MPR tidak sungguh-sungguh memperhatikan aspirasi masyarakat tentang arah dan materi perubahan itu.Tengarai atau kekhawatiran seperti ini wajar karena pendapat para ahli yang diundang ke MPR maupun yang digali oleh Panitia Ad Hoc MPR melalui kunjungan kerja dan seminar-seminar tampaknya harus berhadapan dengan kepentingan-kepetingan politik jangka pendek di dalam MPR, sehingga banyak di antaranya yang tidak diserap atau diserap berdasarkan kompromi-kompromi. ${ }^{62}$ Forum Rembuk Nasinal di Bali menyimpulkan bahwa sangat berbahaya jika amandemen UUD hanya dipercayakan pada MPR.

Memang menurut UUD yang berlaku sekarang ini wewenang untuk mengubah UUD ada di tangan MPR sehingga adanya sebuah Dewan Perancang Konstitusi akan tidak sesuai dengan prosedur yang ditentukan oleh konstitusi itu sendiri. Tetapi ketentuan tentang prosedural ini tetap bisa dipenuhi asalkan ada tahap akhir pengesahan hasil kerja komisi itu tetap dilakukan MPR. Jadi komisi ini hanya menyiapkan rancangan perubahan agar prosesnya stril dari kepentingan-kepentingan poltik yang sempit dan hasilnya sesuai dengan kebutuhan objektif negara dan bangsa Indonesia yang inging menyongsong masa depannya secara lebih baik. ${ }^{63}$

Oleh karena MPR telah menetapkan untuk melanjutkan dan menyelesaikan masalahmasalah mendasar yang masih tersisa dari proses amandemen maka ada baiknya Badan Pekerja MPR segera membentuk sebuah komisi negara yang diserahi tugas untuk menyiapkan rancangan amandemen yang komprehensif, objektif, dan steril dari kepentingan-kepentingan politik sesaat. Hasil kerja komisi tersebut nantinya diserahkan kepada MPR untuk dibahas dan disahkan sesuai dengan ketentuan Pasal 37 UUD 1945.

\section{Politik Hukum Jangka Panjang}

Untuk kasus-kasus pelanggaraan HAM berat yang terjadi di masa lalu dan sekarang, sedang membawa kita ke dalam sebuah pergulatan berat untuk menyelesaikannya haruslah segera diselesaikan dengan pilihan politik hukum yang tegas apakah akan

${ }^{62}$ Keputusan Forum Rembuk Nasional yang dikeluarkan tanggal 1 Juli 2000 cukup menarik perhatian. Tetapi sebenarnya gagasan ini bukan hal baru sebab sebelum itu beberapa pakar telah melontarkannya lebih dulu seperti dapat dilihat pada Harian Jawa Pos edisi, 11dan 12 Mei $2000 \mathrm{HIm}$. 2 dan berita utama Harian Kompas tanggal 21 Juni 2000.

${ }^{63}$ Lihat juga dalam Moh. Mahfud MD. "Amandemen 'Kompromi' Setengah Hati" Majalah Forum No. 22, 3 September 2000. HIm. 62: Juga dalam Bagir Manan. "Kabinet Gus Dur dan Pembaruan UUD". majalah Forum No. 23. 10 September 2000. HIm. 63. 
sungguh diselesaikan secara hukum sampai di pengadilan ataukah akan memberi baju hukum bagi proses pemutihan dan rekonsiliasi secara elegan. Pilihan atas kedua alternatif ini sama-sama mempunyai alasannya baik secara hukum maupun politik.

Salah satu aspirasi yang sangat kuat disuarakan di dalam proses reformasi adalah peradilan atau penyelesaian hukum untuk kasus-kasuss pelanggaran HAM dan KKN yang terjadi di era Orde Baru. Bahkan aspirasi ini berhasil didesakkan oleh gerakan mahasiswa untuk menjadi bagian penting dari ketetapan-ketetapan Sidang Istimewa MPR bulan November 1998 meskipun harus melalui kekerasan politik yang kemudian dikenal sebagai Peristiwa Semanggi II. Pada waktu itu kuat disuarakan agar pelanggaran HAM dan dugaan KKN yang dilakukan oleh mantan Presiden Soeharto dan kroni-kroninya dibawa kepengadilan untuk diselesaikan secara hukum.

Namun, sampai saat ini upaya penyelesaian hukum atas kasus pelanggaran HAM dan KKN di masa lalu itu dapat dikatakan belum menghasilkan apa-apa, bahkan belum memiliki konsep tentang arah penyelesaian yang jelas dan lebih bersifat sporadis. ${ }^{64}$ Dari pergulatan yang terjadi selama ini terdapat dua kendala utama dalam upaya untuk menyelesaikan secara hukum atas pelanggaran HAM dan dugaan KKN dimasa lalu: pertama, kendala teknis-prosedural yang menyangkut pembuktian secara hukum dan ketersediaan aturan hukum; kedua, kendala politis yang ditandai oleh adanya kekuatan yang besar untuk menghambat upaya penyelesaian melalui pengadilan.

\section{1) Kendala Teknis Prosedural}

Secara teknis-prosedural dengan operasi intelijen ketika pelanggaran HAM berat dilakukan dengan berlalunya waktu yang cukup lama tidak mudah untuk menemukan bukti-bukti yang kuat untuk membawa kasuskasus tersebut ke pengadilan. Juga belum dimilikinya perangkap hukum yang cukup tegas bagi upaya penyelesaian kasus pelanggaran HAM berat sehingga tampak agak aneh bahwa diprosesnya kasus itu sambil (secara bersamaan) berusaha membuat dan menyiapkan aturan hukum yang akan digunakan, seperti membuat UU No. 39 Tahun 1999 tentang Hak Asasi Manusia, membuat Peraturan Pemerintah Pengganti UndangUndang No. 1 Tahun 1999 tentang Pengadilan Hak Asasi Manusia yang kemudian ditolak oleh DPR yang sudah mulai dibahas di DPR. Penyiapan RUU Pengadilan HAM itu sendiri kemudian menimbulkan masalah hukum tersendiri ketika dihadapkan pada pertanyaan tentang bisa atau tidaknya UU itu nantinya diberlakukan (secara surut) terhadap kasus yang terjadi sebelum adanya Undang-Undang itu. Pertanyaan itu muncul berkaitan dengan azas legalitas yang menjadi salah satu prinsip di dalam hukum pidana kita; apalagi perubahan

64"Belum ada, Konsep Penyelesaian Kasus HAM." dalam Kompas Cyber Media. Edisi 28 Juni 2000. Sejauh menyangkut perlunya kepastian konsep dan arah dalam Kasus Orang Hilang dapat dilihat misalnya pandangan Herman Sulistyo di dalam "Kasus Orang Hilang: Pengungkapan dan Penyelesaian Masalah". Seri Publikasi No. 1/April 2000. Kantor Negara Urusan HAM RI. HIm. 47-50. 
kedua UUD 1945 hasil Sidang Tahunan MPR 2000 memuat Pasal 281 yang dapat saja ditafsirkan menolak azas retroaktif itu. ${ }^{65}$ Azas retroaktif ayang menawarkan formulasi pemberlakukan oleh UU atas kasus masa lalu kemudian muncul dalam perdebatan publik tentang pemberlakukan UU Pengadilan HAM itu $^{65}$ yang seumpama pun prinsipnya dapat disetujui masih menimbulkan pertanyaan juga tentang batas waktu jangkauan ke belakang dari azas retroaktif.

Dalam pada itu terlihat juga bahwa telah terjadi tolak tarik dalam proses penyelidikan dan penyidikan atas kasus-kasus masa lalu itu antara prinsip kepastian hukum dan prinsip penegakan keadilan. Sulitnya menemukan bukti-bukti formal atas pelanggaran atau bahkan adanya bukti formal bahwa sesuatu yang dipersoalkan itu telah ada aturan resmi yang membenarkannya telah dijadikan alasan oleh para penasehat hukum (calon) tersangka untuk menyatakan tidak adanya pelanggaran hukum dan karenannya, "demi kepastian hukum", kliennnya harus dibebaskan; sementara tindakan nyata atau akibat dari berbagai pelanggaraan itu telah nyata-nyata ada dan dirasakan oleh masyarakat sehingga para pihak yang berseberangan muncul gumpalan asprasi agar, "demi keadilan", kasus-kasus itu segera dibawa ke pengadilan. Prinsip demi kepastian hukum dan demi tegaknya keadilan yang seharusnya djadikan prinsip yang saling melengkapi kemudian dijadikan alat tolak tarik untuk mencari kemenangan dalam menangani perkara. ${ }^{67}$ itulah kendala teknis prosedural hukum yang dihadapi pada saat ini dalam upaya penyelesaian kasus pelanggaran HAM dan KKN yang terjadi di masa lalu.

\section{2) Kendala Politis}

Adapun kendala politis yang terkait dengan upaya tangan-tangan kuat untuk menghalangi proses hukum atas pelanggaran HAM dan KKN menjadi jauh lebih serius daripada persoalan-persoalan teknis prosedural hukum seperti yang dikemukakan di atas. Kendala politis ini pertama-tama dapat dikaitkan dengan masih banyaknya pejabat penting di birokrasi pemerintahan yang secara langsung maupun tidak langsung, terkait dengan banyak pelanggaran yang dilakukan oleh rezim Orde Baru. Seperti diketahui sistem yang dibangun oleh Orde Baru telah memaksa banyak pejabat masuk dalam jebakan sistem yang, mau tidak mau, meyeretnya terlibat dalam KKN dan pelanggaran atas $K K N$ dan pelanggaran atas HAM. Mereka yang masih

${ }^{65} \mathrm{Pasal} 281$ ini menyebutkan bahwa setiap orang berhak untuk tidak dituntut dengan hukuman yang diberlakukan secara surut. Perbuatan yang dilakukan sebelum adanya UU yang melarang dan mengancam dengan hukuman tertentu tidak dapat dihukum dengan UU yang kemudian ada atau diadakan.

${ }^{66}$ Sebenarnya bisa saja azas retroaktif diberlakukan asalkan pemberlakuannya ditetapkan dalam satu UU, sebab asas legalitas itu merupakan muatan UU (Pasal 1 KUH Pidana). Prinsipnya kalau ada isi UU baru yang mengubah isi UU lama maka isi UU barulah yang berlaku. Selain itu azas retroaktif bisa diberlakukan untuk melaksanakan perintah konstitusi dalam menegakkan keadilan.

${ }^{67}$ Lihat dalam "Ambiguitas Orientasi Negara Hukum. Dalam Moh. Mahfud MD. Hukum dan Pilar-pilar Demokrasi. Gama Media dan Ford Foundation. 1999. 
tersebar di berbagai instansi atau lembaga negara dari tingkat. Pusat sampai Daerahdaerah ini sangat mungkin tidak suka, bahkan takut terhadap akibat, setiap upaya proses hukum atas pelanggaran-pelanggaran HAM dan KKN di masa lalu karena mereka pun akan terkena giliran manakala proses hukum benarbenar dilaksanakan sebab mereka pun, mungkin semula tanpa dikehendaki oleh dirinya sendiri dan terpaksa terlibat menjadi bagian dari pelaku pelanggaran HAM dan KKN di masa lalu. Masih banyaknya aparat penegak hukum dn pejabat lain korup sebagai warisan Orde Baru diberbagai lembaga negara dan lembaga pemerintahan yang sebenarnya gamang pada upaya mengadili pelanggaran HAM dan KKN itu diperkuat oleh barisan kroni mantan pejabat korup yang kini masih banyak berkeliaran di luar lembagalembaga resmi (termasuk mungkin menyusup ke parpol-parpol) tetapi memiliki kekayaan yang besar untuk melakukan upaya-upaya penghambatan.Mereka ini dapat menempuh berbagai cara untuk memblokade setiap upaya penuntasan seara hukum ke pengadilan terutama yang menyangkut mantan Presiden Soeharto. ${ }^{68}$
Upaya blokade atau penghambatan terhadap upaya penyelesaian hukum atas kasus-kasus masa lalu ini bahkan banyak dipercaya telah muncul dalam bentuknya yang sangat mengerikan yakni pemicuan kerusuhan dan tindak kekerasan politik yang sambung menyambung di berbagai tempat di tanah air sehingga pelanggaran HAM secara massif dan berat kembali terjadi tanpa dapat dikendali oleh pemerintah atau aparat keamanan. Jaksa Agung Marzuki Darusman dan Mantan Menteri Pertahanan Juwono Sudarsono memberikan konfirmasi atas pandangan seperti ini. Pada sidang kabinet tanggal 3 Juli 2000 lalu, Jaksa Agung mengatakan bahwa ada korelasi antara berbagai gejolak dan tindak kekerasan dengan pemeriksaan di Kejaksaan Agung, ${ }^{69}$ terbukti selalu muncul gejolak di tengah-tengah masyarakat ketika pemeriksaan kasus masa lalu di Kejaksaaan Agung semakin intensif dan mengarah pada figur Soeharto atau kroninya. Ketika masih menjabat sebagai Menteri Pertahanan Juwono Sudarsono bahkan menyatakan dengan tegas bahwa keluarga Cendana dan kroni-kroninya terlibat di dalam berbagai kerusuhan karena mereka takut kalau kasus-kasus pelanggaran mereka diajukan ke pengadilan. ${ }^{70}$

\footnotetext{
B8Moh. Mahfud Md. "Sidang Tahunan MPR untuk Rekonsiliasi". Dalam harian Pikiran Rakyat. Edisi 10 Juli 2000.

${ }^{69 "}$ Ada Korelasi Antara Peningkatan Gejolak dengan Pemeriksaan di Kejaksaan Agung." Dalam Kompas Cyber Media. 3 Juli 2000.

${ }^{70}$ "Soal Kroni Cendana, Bermain Sejak Zaman Habibie". Dalam Tempo Interaktif . Edisi 6 Juli 2000. Pernyataan Menhan Juwono Sudarsono juga banyak dikutip media massa Indonesia tanggal 4 dan 5 Juli 2000.
} 
Oleh sebab itu politik hukum terhadap kasus pelanggaran $\mathrm{HAM}$ dan $\mathrm{KKN}$ di masa lalu untukjangka pendek ini perlu mengalkulasi kemungkinan pemutihan melalui pencarian kebenaran dan rekonsiliasi di luar pengadilan. Gagasan pemutihan berarti menganggap selesai semua masalah yang: terjadi di masa lalu dan melakukan rekonsiliasi nasional untuk bersama-sama membangun Indonesia menyongsong masa depan. Siapa pun yang kemudian melakukan pelanggaran lagi setelah dilakukan pemutihan dan rekonsiliasi diancam dengan hukuman yang sangat berat. Tentu saja fakta-fakta dan kebenaran terjadinya kasus pelanggaran itu harus dianggap diungkap lebih dulu berdasar pengakuan bersalah, penyesalan, dan permintaan maaf tapi dengan jaminan tidak akan diadili. Bersama dengan itu ada kesediaan dari pelaku untuk mengembalikan kekayaan yang didapat secara tidak sah serta membantu pemerintah dalam memberikan kompensasi, restitusi, dan rehabilitasi atas korban atau keluarga korban.

Asumsi yang mendasari politik hukum pemutihan yang berintikan rekonsiliasi ini adalah kepercayaan bahwa kendala teknis prosedural dan kendala politis akan sangat menyulitkan penyelesaian kasus ini secara baik. Kendala teknis prosedural hukum seperti yang digambarakan di atas akan menyulitkan pembuktian dan penerapan perangkat hukum sedangkan kendala politis akan menghadapkan pada pilihan-pilihan pahit yakni kerusuhan dan kekerasan politik proses pengadilan itu diteruskan. ${ }^{71}$ Meskipun pengambilan keputusan ini bertentangan dengan semangat awal reformasi yang meneriakkan supremasi hukum dan menghendaki kasus-kasus ini diselesaikan secara hukum di pengadilan, namun solusi ini penting untuk dipertimbangkan. Penekanannya adalah pembicaraan tentang kemungkinan pemutihan atau rekonsiiasi ini bukan menjadi wewenang pelaku kejahatan dan rezim penguasa baru, melainkan menjadi hak pemerintah (dalam arti luas) dari para korban. ${ }^{72}$ bahkan menjadi hak pemerintah baru, korban pelanggaran, dan elemenelemen masyarakat yang nyata-nyata memperjuangkan reformasi. Apabila hal itu disepakati maka sebagai pilihan yang dianggap lebih realistis realisasinya harus didahului dengan pemberian baju hukum, misalnya dengan ketetapan MPR atau dengan UU yang menandakan bahwa itu merupakan keputusan rakyat. Karena setiap tindakan bentuk menyelamatkan rakyat dan keutuhan bangsa harus dilakukan oleh negara, maka tindakan penyelamatan itu sendiri merupakan hukum yang lebih tinggi dari hukum yang telah ada, asalkan alasan-alasannya bisa diterima oleh rakyat dan bukan merupakan tindakan sepihak oleh penguasa.

Tetapi apabila pilihan kebijakan seperti itu ditolak maka pemerintah harus melakukan

\footnotetext{
${ }^{71}$ Mengomentari hiruk pikuk atas pengadilan mantan Presiden Soeharto pada akhir Agustus lalu seorang pejabat tinggi menggambarkan kospirasi sifat masyarakat atas peradilan tersebut dengan mengatakan bahwa kira-kira 10\% menginginkan Pak Harto diadili dengan tegas, 10\% menginginkan agar Pak Harto tidak diadili dan diampuni tanpa syarat, sedangkan yang $80 \%$ sisanya lebih suka penyelesaian secara rekonsiliasi.

72Lihat juga dalam Munir. "Komisi 'kompromi' kebenaran". Dalam majalah Forum. Edisi 25 Juni 2000.
} 
langkah-langkah radikal dengan melakukan pembersihan atau amputasi terhadap pejabatpejabat warisan Orde Baru yang diduga terlibat KKN dan pelanggaran HAM serta melakukan tindakan tegas terhadap terhadap setiap gejala timbulnya kekerasan politik dan kerusuhan-kerusuhan. Apabila pemerintah masih bersikap setengah-setengah, atau mengatakan akan menyelesaikan secara hukum tetapi tidak disertai dengan tindakan yang benar-benar tegas maka kita hanya akan berjalan di tempat dan dan tidak bisa melaksanakan agenda reformasi yang lain, bahkan mungkin akan menerima resiko yang jauh lebih pahit yakni timbuinya berbagai kerusuhan yang terus menerus dan ancaman disintegrasi yang mengerikan.

\section{Simpulan}

Peliknya penanganan bagi penyelesaian kasus-kasus pelanggaran HAM dan KKN di masa lalu, baik pada kendala teknis prosedural hukum yang menyangkut pembuktian dan penerapan perangkat hukum maupun kendala politis yakni pilihan-pilihan pahit seperti kerusuhan dan kekerasan politik yang terjadi ketika proses pengadilan itu digelar, maka kebijaksanaan untuk jangka pendek ini perlu mengkalkulasi kemungkinan pemutihan melalui pencarian kebenaran dan rekonsiliasi di luar pengadilan. upaya ini melibatkan berbagai lapisan masyarakat, terutama elemen-elemen kekuatan reformasi untuk mengalkulasi secara mendalam dan sampai pada kesimpulan bersama. Pembicaraan tentang kemungkinan .pemutihan atau rekonsiliasi ini bukan menjadi wewenang pelaku kejahatan dan rezim penguasa baru, melainkan menjadi hak pemerintah (dalam arti luas) dari para korban. Bahkan menjadi hak pemerintah baru, korban pelanggaran, dan elemen-elemen masyarakat yang nyata-nyata memperjuangkan reformasi. Apabila hal itu disepakati maka sebagai pilihan yang dianggap lebih realistis realisasinya harus didahului dengan pemberian baju hukum, misalnya dengan ketetapan MPR atau dengan UU yang menandakan bahwa itu merupakan keputusan rakyat. Karena dalam adagium yang diterima sebagai prinsip hukum yakni sales populi suprema lex yang berarti keselamatan rakyat adalah keselamatan hukum yang tertinggi, maka setiap tindakan bentuk penyelamatan rakyat dan keutuhan bangsa harus dilakukan oleh negara. Sedangkan untuk kebijaksanaan jangka panjang, politik hukum HAM harus memberi landasan konstitusional bagi keharusan munculnya sistem politik yang demokratis melalui perubahan atau amandemen atas UUD 1945 (dalam arti yang luas). $\Xi$

\section{Daftar Pustaka}

Alagappa, Mutiah. 1995. Political Legitimacy in Southeast Asia, the Quest for moral Authority. California: Stanford University Press.

Alkostar, Artidjo. "Hak Asasi manusia dalam prospek Penegakan Hukum Dewasa ini." Disampaikan sebagai Dies Rede pada Sidang Terbuka Senat Universitas Islam Indonesia Panitia Dies natalis UII ke-51 tanggal 29 Desember 1994.

Buyung Nasution, Adnan. 1992. The Aspiration for Constitusional Government in Indonesia, a Socio-Legal Study of the 
Indonesian Konstituante 1956-1959. Jakarta: Pustaka Sinar Harapan.

Gaffar, Afan. 1999. Politik Indonesia, Transisi Menuju Demokrasi. Yogyakarta: Pustaka Pelajar.

Haris, Syamsuddin dkk. 1997. Pemilihan umum di Indonesia, Telaah atas Struktur, Proses dan Fungsi. Jakarta: PPW-LIPI.

Henry, Marrymann John. 1969. The Civil Law Tradition. California: Stanford University Press.

Kobayashi, Naoki. "Different Concepts of Modern Constitution." Dalam Senshu Hongaku Ronshu. 39 (Bassatsu). 1984.

Mahfud MD, Moh. "UU Politik, Keormasan dan Instrumentasi Hak Azasi Manusia." Jurnal Hukum No. 10Nol. 5/1998.

- 1998. Politik Hukum di Indonesia. Jakarta: LP3ES.

- "Mengantisipasi Kekerasan Politik pada Pemilu 1999". Makalah untuk diskusi tentang Kekerasan dalam Pemilu 1999. Diselenggarakan oleh Universitas Atma Jaya. Yogyakarta 2 Maret 1999.

- - "Kekuasaan sebagai Sumber Kekerasan Politik." Makalah pada seminar tentang Negara, Masyarakat dan Kekerasan. Diselenggarakan oleh Fakultas Hukum Ull. Yogyakarta 20 Juli 1999.

1999. Amandemen UUD 1945 untuk Reformasi Tata Negara. UII Press.
- - Pergulatan Politik dan Hukum. Gama Media dan Ford Foundation. 1999.

—. "Berbagai Produk Hukum tentang HAM yang Tampak Tumpang Tindih." Makalah untuk Seminar tentang Implementasi UU HAM. Diselenggarakan oleh ATMA-IKADIN, Kantor Sospol Pemda Solo, Solo Pos, dan Bakom PKB Kodya Solo. Surakarta tanggal 29 Nopember 1999.

_._. "Amandemen 'Kompromi' Setengah Hati" Majalah Forum No. 22, 3 September 2000.

_. Hukum dan Pilar-pilar Demokrasi. Gama Media dan Ford Foundation. 1999.

-. "Sidang Tahunan MPR untuk Rekonsiliasi". Dalam harian Pikiran Rakyat. Edisi 10 Juli 2000.

Mc Truman Kahin, Gerge. 1952. Nationalisme Revolution in Indonesia. New York: Cornell University Press, Ithaca. 1952.

Noer, Deliar. 1998. Pemikiran Politik di Negari Barat. Cet. Ill. Bandung: Mizan.

Wignyosoebroto, Soetandyo. "Hak-hak Azasi Manusia, Demokrasi dan Pelaksanaannya di Indonesia, Sebuah Tinjauan Sosio-kultural dari Prespektif Sejarah." Makalah pada Diskusi IImiah. Di PusatAntar Universitas, Studi Sosial, Universitas Gadjah Mada. Yogyakarta. 18 Oktober 1994. 
—_. "Konștitusi dan Konstitualisme." Makalah untuk lokakarya

- Konstitusionalisme untuk kedaulatan Rakyat. Diselenggarakan oleh Konsorsium Reformasi Hukum . Nasional KRHN) di Surabaya. Tanggal 15-16 Oktober 1998.

Whère, KC. 1951. Modern Constitutions. $\therefore$. London: Oxford University Press. 1951.

Sanit, Arbi. "Memahami Kekerasan Politik". Dalam fakultas Hukum UII LKBH. Kekerasan dalam Politik yang Over Acting (sic). Yogyakarta. 1998.

S Corwin, Edward dan JW Peltason. 1967. Understanding the Constitution. New York, Chicaago, San Fransisco, Toronto, London: Rinehart and Wilson lnc.

Strong, CF. 1952. "Modern Political Constitutions." An Introduction to the Comparative Study of Their History and .Existing Form. London: Sidgwick \& Jackson Ltd. 1952.

Thoolen, Hans. 1987. Indonesia and the Rule of Law, Twenty Years of New Order Government. London: Frances Printer (Publiser).
Yamin, Muhammad. Naskah Persiapan Undang Undang Dasar 1945. Cet. I Jilid I. Yayasan Penerbit Siguntang. 1959.

Makalah untuk lokakarya Konstitusionalisme untuk Kedaulatan Rakyat yang diselenggarakan oleh Konsorsium Reformasi Hukum Nasional (KRHN). Surabaya tanggal 15-16 Oktober 1998.

Detak. 9 Oktober 1998.

Forum. Edisi 25 Juni 2000.

Forum No. 23. 10 September 2000.

Jawa Pos. Edisi, 11dan 12 Mei 2000

Kompas Cyber Media. 3 Juli 2000.

Kompas Cyber Media. Edisi 28 Juni 2000.

Kompas tanggal 21 Juni 2000.

Kompas Cyber Media. Edisi 28 Juni 2000.

Seri Publikasi No.1/April 2000.Diterbitkan oleh Kantor Menteri Negara Urusan HAM republik Indonesia.

Seri Publikasi No. 1/April 2000. Kantor Negara Urusan HAM Rl.

Tempo. Edisi 12-18 Juli 1999.

Tempo Interaktif . Edisi 6 Juli 2000. 